21. Чернявская В.Е., Молодыченко Е.Н. речевое воздействие в политическом, рекламном и интернетдискурсе. - М.: ЛЕНАНД, 2017. - 176 с.

22. Чугунова С.А. Психолингвистика: история и перспективы развития: учебное пособие. - Брянск: Курсив, 2012. - 171 с.

23. Шейгал Е.И. Семиотика политического дискурса. - М.: ИТДГК «Гнозис», 2004.

24. Шелестюк Е.В. речевое воздействие: онтология и методология исследования: монография. - М.: ФЛИНТА: Наука, 2014. - 344 с.

25. Академик [Электронный ресурс]. - Режим доступа:https://dic.academic.ru/dic.nsf/ruwiki/1058809.

26. Лингвистический Энциклопедический словарь[электронный ресурс]. $\quad$ - Режим доступа:http://tapemark.narod.ru/les/404d.html.

\title{
Сафина Л.М. \\ О проведении творческих письменных работ на занятиях по русскому языку в группах учащихся-иностранцев в техническом вузе
}

Московский автомобильно-дорожный государственный технический университет (МАДИ)

(Россия, Москва)

doi: 10.18411/spc-25-01-2018-04

idsp: 000001:spc-25-01-2018-04

\section{Аннотация}

В статье речь идет о том, как готовится, проводится и анализируется творческая письменная работа в техническом вузе. Предлагается анализ проведения творческой письменной работы на тему по специальности, дается характеристика ее особенностей.

Ключевые слова: творческая письменная работа, лексический и грамматический материал, специальность, сочинение, изложение

\section{Abstract}

This article is about the creating, leading and analysing of the creative output in technological universities. There is the analysis of the practical work on a topic with a degree in any, distinctive characteristics of it's specific aspects are given.

Key words: creative output, lexical and grammar information, specialization, composition, narration

Всистемезанятийпорусскомуязыкусиностраннымистудентамиособоеместозаним аютписьменныеработы. Следует отметить, что творческие виды письменных работ активное и действенное средство развития речи учащихся.

Порядок проведения письменных работ, их целевая установка и общая направленность позволяет разделить их на две условные категории:

1) письменные работы, при выполнении которых студенты тренируются в изучаемом материале (диктанты, ответы на вопросы, упражнения грамматического и грамматико-лексического типа) или делают попытки воспроизвести «чужой» текст в нем же данными языковыми средствами (пересказ без дополнительного задания, изложение);

2) письменные работы, в которых студенты опираются на изученный за определенный отрезок времени материал (лексический, грамматический и фактический), описывают увиденное и пережитое, анализируют тексты, рассуждают и делают выводы. Это может быть рецензия, сочинение по художественному тексту, сочинение по презентации, изложение с элементами сочинения, сочинение на свободную тему, сочинение на тему по специальности. Для всех этих работ характерен ведущий элемент самостоятельности, творчества учащихся, основанного на ранее изученном материале, поэтому их можно условно объединить под общим названием «Творческие виды письменных работ». 
С одной стороны, при проведении творческих видов письменных работ закрепляется материал, воспринятый студентами на слух при объяснении преподавателя или при выполнении самостоятельных работ студента, предусмотренных в рабочей программе дисциплины «Русский язык как иностранный». С другой стороны, творческие письменные работы выявляют и выправляют те ошибки в речи иностранных студентов, которые выпали из поля зрения преподавателя во время контроля над устным ответом. Подготовка к творческим письменным работам способствует расширению активного словаря студентов, а работа над ошибками, редактирование и переписывание исправленных работ развивает у них навыки самоконтроля и одновременно дает им материал для самостоятельного повторения пройденного.

Творческие письменные работы способствуют развитию у студентов навыков письменной речи. На факультетах и на специальных кафедрах иностранные студенты бакалавры, магистранты и аспиранты должны владеть навыками если не абсолютно правильной, то во всяком случае вполне понятной письменной речи с использованием определенной лексики (запись и конспект лекционного и книжного материала) и уменьем составить связный, логический рассказ на определенную тему (доклад, реферат, курсовая работа, диссертация). Проведение творческих видов письменных работ способствует и помогает выработке этих навыков и помогает учащимся в их непосредственной работе на факультетах.

Следует отметить и то, что регулярное и систематическое проведение творческих видов письменных работ пробуждает у студентов интерес к особенностям строя русского языка, будит и развивает их творческие возможности.

При сравнении работ одного и того же студента за определенный отрезок времени, можно убедиться в том, на сколько изменились показатели в овладении языком. Если же сравнивать работы, написанные через определенные промежутки времени, можно заметить не только формальное продвижение учащихся, но и развитие интереса к делу, совершенствование стиля, все более глубокое понимание целей и задач работы. Это позволяет оценивать работы не только как итоговые, обобщающие, но иногда даже и зачетные.

Творческие письменные работы являются итогом и обобщением прохождения определенного, запланированного материала:

- чтения и анализа текста или нескольких текстов (согласно плану воспитательной работы на кафедре, например, проведение заседаний клуба «Литературная гостиная в МАДИ»);

- изучения грамматической темы (в рамках проведения внутривузовской олимпиады по русскому языку «Занимательная грамматика» среди иностранных бакалавров, магистрантов);

- проведения дискуссий (в рамках работы разговорного клуба «Русская матрешка» в МАДИ);

- проведения бесед и экскурсий.

При составлении рабочего плана студентов на определенный отрезок занятий, при планировании тем и материала на семестр учитывается, какую базу даст та или иная изучаемая на занятиях тема для очередной творческой письменной работы. Таким образом, творческие письменные работы учащихся заранее планируются, темы их связаны с темами занятий, намеченными для прохождения в данном семестре, а сами работы базируются на определенном идейно-тематическом и связанном с ним лексическом и грамматическом материале. Согласно плану учебно-воспитательной работы на кафедре, намечается несколько обобщающих тем и одновременно планируется определенное количество творческих письменных работ. К концу учебного года некоторые из представленных тем выводятся на экзамен по русскому языку в качестве тем для беседы. Вот, например, план работы на семестр в группах 2-го 
курса: «Защита окружающей среды: природные заповедники России», «Природные заповедники в родной стране», «Известные выпускники МАДИ» (по выбору бакалавра»), «Культурные традиции родной страны», «Известный современный русский писатель» (по выбору бакалавра) и т.п.

Так как сама формулировка темы работы может и помогать студентам при написании работы, запланированные заранее темы творческих письменных работ должны быть продуманы и с точки зрения формулировки. В отдельных случаях формулировка темы может затруднить написание письменной работы. С одной стороны, тема творческой письменной работы не должна быть слишком широкой, в таком случае понадобится много дополнительного материала для ее наполнения. С другой стороны, темы должны базироваться на достаточном и известном, изученном на занятиях материале. Для пояснения и уточнения задания темы могут снабжаться подзаголовками, направляющими мысль учащихся и ограничивающими материал. Так тема «Моя специальность», например, дается подзаголовками: «Человек моей профессии»; хорошие работы пишутся на темы-вопросы, заставляющие студента что-то доказать, делать какие-то выводы, например, «Где я буду работать?». Определенная направленность в формулировке темы помогает полнее и правильнее ответить на нее. При ограниченном времени и сравнительно небольшом лексическом запасе учащихся ясность и четкость в формулировке задания является необходимым условием хорошего выполнения работы. Рецензия, отдельные виды работ по литературному тексту, тезисы и др. требуют даже предварительного теоретического ознакомления, подробного объяснения того, как надо выполнять именно этот вид работы.

Учащиеся часто затрудняются в планировании имеющегося у них материала и не знают, как построить работу, хотя и обладают достаточным запасом фактических знаний по теме и необходимым для выполнения работы словарным и грамматическим минимумом. Во время занятий мы учим «писать по плану», «рассказывать по плану» и т.П., все же этот вид работы не столь доступен учащимся на продвинутом этапе обучения, как это кажется на первый взгляд. А между тем составление плана - это один из важных моментов в написании творческой письменной работы любого вида, основа большинства хороших сочинений. План помогает студентам лучше понять предмет сочинения и определённее сформулировать выводы по данной теме. Умение планировать помогает четкости выражения мыслей, сохранению правильных пропорций отдельных частей работы.

Стоит отметить, что обучая писать по-русски, мы одновременно развиваем умение письменно выражать свои мысли. Стоит отметить, что не все студенты умеют это делать и на своем родном языке. Они зачастую не могут спланировать и расположить материал, когда появляется в этом необходимость, например, при написании курсовой работы, диплома и диссертации, подготовки выступлений на студенческих конференциях, составлении презентаций и т.д.

Таким образом, важным этапом работы над творческими письменными работами, вырабатывающим у иностранных студентов необходимых им навыков обобщать, логически располагать и связывать материал является составление плана.

При анализе работ стоит обратить внимание на выработку у учащегося индивидуального стиля письма. При регулярном проведении и анализе творческих письменных работ у преподавателя появляется возможность индивидуального подхода, что, несомненно, помогает развитию общих языковых способностей студента иностранца.

Наряду с этими общими для всех видов моментами существуют некоторые специфические особенности в формах проведения отдельных видов творческих письменных работ. 
Далее речь пойдет об анализе сочинения на тему по специальности. Выбор обусловлен наличием опыта работы в техническом вузе и наличием практического опыта в их проведении.

На первый взгляд работы по теме специальности во многом близки к сочинениям на свободную тему. Они нужны и полезны нашим студентам, поскольку развивают навыки, необходимые им в непосредственной работе на факультетах. Они помогают накоплению и активизации специальной лексики, введению в практику грамматических конструкций современной научной речи, способствуют развитию навыков цитирования, конспектирования и обобщения книжного и лекционного материала. Темы работы по специальности сначала формулируются в общем виде, позже ограничиваются и конкретизируются. Написание данного вида работы по одновременно может контролировать знания студентов в области специальности и может вводить необходимый для студентов лексический и грамматический материал. Оба варианта применимы и полезны на всех этапах обучения, включая выпускной экзамен. Материалы для работы: специальные тексты по специальности, научнопопулярная литература, материалы конференций по направлению подготовки и т.п. во время подготовительного этапа работы особое место уделяется работе синтаксисом научной речи.

Подводя итоги, можно сделать следующие выводы:

1. определенное место в системе занятий по русскому языку со студентамииностранцами занимают творческие письменные работы.

2. Творческие письменные работы после планирования, подготовки и анализа служат действенным и активным средством для скорейшего и прочнейшего усвоения материала.

3. Как показывает опыт, написание данного вида работ позволяет контролировать пополнение словарного запаса специализированной лексики инженера.

$$
* * *
$$

1. А. Н. Барыкина, В.П. Бурмистрова, В.В. Добровольская, Пособие по развитию навыков письменной речи. - Москва: Русский язык, 1978.

2. Проблемы преподавания филологических дисциплин иностранным учащимся : : Материалы 4-й Международной научно -методической конфе- ренции. - Воронеж : ИПЦ «Научная книга», 2016. $467 \mathrm{c.}$

\section{Сергеева С.H. \\ Формирование читательской компетенции учащихся на уроках литературы в основной школе}

МБОУ"СОШ №37

doi: $10.18411 / s p c-25-01-2018-05$

(Россия, Набережные Челны)

idsp: 000001:spc-25-01-2018-05

\section{Аннотация}

Задача данной статьи - ознакомить читателя с понятиями "читательская грамотность", "читательская компетентность"; показать методики формирования читательской компетентности.

Ключевые слова: школа, учебная деятельность; читательская грамотность, читательская компетентность; методики формирования читательской компетентности.

\section{Abstract}

The task of this article is to acquaint the reader with the concepts of "literacy", "reader competence"; show methods of forming the reader's competence.

Key words: school, educational activity; reader literacy, reading competence; methods of forming reader competence. 